\title{
Human Herpesvirus 7 in Allogeneic Hemopoietic Stem Cell Transplant Recipients in the Central Clinical Hospital in Warsaw: A Three-Year Survey
}

\author{
Tomasz Dzieciatkowski ${ }^{a, c}$ Maciej Przybylski ${ }^{a, c}$ Grzegorz Wladyslaw Basak ${ }^{b}$ \\ Tigran Torosian $^{\mathrm{b}}$ Wieslaw Wiktor Jedrzejczak ${ }^{\mathrm{b}}$ Grazyna Mlynarczyk ${ }^{\mathrm{a}, \mathrm{c}}$
}

Departments of a Medical Microbiology and ${ }^{b}$ Hematology, Oncology and Internal Medicine, Medical University of

Warsaw, ${ }^{C}$ Department of Microbiology, Public Independent Central Clinical Hospital in Warsaw, Warsaw, Poland

\section{Key Words}

Human herpesvirus $7 \cdot$ Human herpesvirus $5 \cdot$ Hemopoietic stem cell transplant $\cdot$ Real-time PCR

\begin{abstract}
Objectives: Human herpesvirus 7 (HHV-7) is spread worldwide and has been described as a potential pathogen in immunosuppressed patients. Different clinical manifestations have been described including fever and skin rash; HHV-7 may also be a possible cofactor for cytomegalovirus disease in transplant recipients. Materials and Methods: A retrospective review of a group of 58 adult recipients of allogeneic hemopoietic stem cell transplantation was made. Serum samples taken in the range of $0-180$ days after transplant were examined for presence of specific HHV-7 sequences using the quantitative real-time PCR method. $\boldsymbol{R e}$ sults: HHV-7 DNA was detected in plasma samples in 26 (45\%) of the 58 recipients between day 20 and day 65 of transplantation. All of them developed fever of unknown origin; also HHV-5 DNA was detected in plasma samples collected from $11 \mathrm{HHV}-7$-positive patients. None of the described individuals died during detectable HHV-7 or HHV-5 viremia periods. Conclusions: There is a high frequency of
\end{abstract}

detectable HHV-7 viral load in allogeneic stem cell transplant recipients in Poland. Limited availability and sensitivity of serological methods along with the necessity of rapid introduction of antiviral treatment has forced the development of molecular diagnostics. Furthermore, establishment of appropriate procedures for monitoring active HHV-7 infection is important to clarify the virus infection in transplant recipients.

Copyright $\odot 2010$ S. Karger AG, Basel

\section{Introduction}

Human herpesvirus type 7 (HHV-7) belongs to the $\beta$ Herpesvirinae subfamily and is very closely related to HHV-6 and also to HHV-5 (commonly known as cytomegalovirus) [1]. In most people, primary HHV-7 infection occurs between 6 months and 5 years of age, later than HHV-6 [2, 3]. After that, the virus remains latent in the body and reactivates upon host immunosuppression, similar to other HHVs.

The clear association of HHV-7 with human disease has not been recognized, although several cases of exanthema subitum have been linked to HHV-7 [4]. Few case

\section{KARGER}

Fax +4161306 1234

E-Mail karger@karger.ch

www.karger.com
(C) 2010 S. Karger AG, Basel

0300-5526/11/0541-0025\$38.00/0

Accessible online at:

www.karger.com/int
Tomasz Dzieciatkowski, MSc, $\mathrm{PhD}$

Department of Medical Microbiology

Medical University of Warsaw

5 Chalubinski Str, PL-02-004 Warsaw (Poland)

Tel./Fax +48 22599 1778, E-Mail dzieciatkowski@wp.pl 
Table 1. Sequences of primers and the probe used in this work

\begin{tabular}{ll}
\hline Name & Sequence $\left(5^{\prime}-3^{\prime}\right)$ \\
\hline HHV7-p1 & CCC AAC TAT TTA CAG TAC GGT TGG T \\
HHV7-p2 & TTT AGT TCC AGC ACT GCA ATC \\
HHV7-JOE & JOE-CTA TTT TCG GTC TTT CCA ATG CAC GCA-TAMRA \\
\hline
\end{tabular}

reports and small patient series have associated primary HHV-7 infection with hepatitis, upper respiratory tract infections and pancytopenia [2]. HHV-7 involvement has been also implicated in pityriasis rosea, based on the virus isolation from peripheral blood mononuclear cells (PBMC) of patients and molecular detection of HHV-7 DNA in plasma, PBMC and skin lesions [5].

All human $\beta$-herpesviruses - especially HHV-5 have been recognized as important causes of morbidity and mortality in transplant recipients, but the number of studies of HHV-7 infection in immunosuppressed patients is very limited. One of the major problems is crossreaction between HHV-6 and HHV-7 antibodies, which might confuse the results of serological analyses [6]. Some investigators have suggested that HHV-7 may be a possible cofactor for cytomegalovirus disease in transplant recipients. Chan et al. [7] monitored 61 bone marrow transplant recipients by PCR analysis, and found that patients with cytomegalovirus disease were more likely to have concurrent HHV-7 DNA in PBMC prior to onset of disease than were patients with asymptomatic HHV-5 infection. Similar findings have also been demonstrated in renal and liver transplant recipients $[8,9]$.

In a recent study, we tried to summarize retrospective results of the determination of HHV-7 infection status in allogeneic stem cell transplantation recipients. As the infections with HHV-7 are rarely accompanied by clinical symptoms, our first aim was to compare infection status, measured as viral DNA presence in the blood, in the posttransplantation period.

\section{Materials and Methods}

This retrospective study involved patients who received an allogeneic hemopoietic stem cell transplantation (HSCT) and were hospitalized in the Hematology, Oncology and Internal Medicine Clinics, Medical University of Warsaw. In the considered period (from January 2006 to December 2008), there were 58 patients receiving allogeneic stem cell transplantations. Additional criteria for the study included appearance of at least one of the syndromes listed below in the period of 100 days after HSCT: appearance or intensification of graft versus host disease (GvHD), skin rush or neutropenic fever. Monitoring of clinical status of the pa- tients and viral load in blood samples comprised the period of 180 days after HSCT.

Collection of plasma samples from all patients for PCR investigations began at a median of 3 days after transplantation (range 1-7 days) and lasted until a median of 107 days (range 28-180 days). Presence of viral DNA was tested by real-time PCR in sera samples obtained once a week until the 100th day after allogeneic HSCT, and thereafter once every 2 weeks. The median number of blood samples per patient was 13 (range 4-24 samples). A total of 574 samples obtained from 58 patients were examined using realtime PCR. Viral DNA was extracted from $200 \mu$ l of plasma, using a High Pure Viral Nucleic Acid Kit ${ }^{\circledR}$ (Roche Diagnostics) in accordance with the manufacturer's instructions.

For the detection of HHV-7, a real-time PCR (qPCR) assay with fluorescent TaqMan probes, complementary for the sequence lying within the amplified product, was used. Tests were run on the LightCycler 2.0 instrument (Roche Diagnostics) with a modified in-house method described below [10]. A highly conservative region of $\mathrm{HHV}-7$ genome encoding major capside protein (U57) was chosen (GenBank, U43400), and a set of primers was developed, as well as the probe, labeled with the fluorophore reporter JOE on the $5^{\prime}$ end and with TAMRA quencher on its $3^{\prime}$ end (Oligo ${ }^{\circledR}$; table 1$)$.

Investigations were performed using the reaction mixture TaqMan Master Kit ${ }^{\circledR}$ (Roche Diagnostics). Besides chemicals supplied by the kit producer, the final reaction mixture contained $5 \mu \mathrm{l}$ of isolated viral DNA, $2.75 \mu \mathrm{M}$ of HHV7-p1 primer, $3.25 \mu \mathrm{M}$ HHV7-p2 primer and $1.50 \mu \mathrm{M}$ HHV7-JOE probe, in a total volume of $20 \mu \mathrm{l}$. Amplification was performed with activation of the thermostable hot-start DNA polymerase for $10 \mathrm{~min}$ at $95^{\circ}$, followed by 45 cycles comprising denaturation $\left(15 \mathrm{~s}\right.$ at $\left.95^{\circ}\right)$, primer annealing $\left(15 \mathrm{~s}\right.$ at $\left.60^{\circ}\right)$ and strand elongation $\left(15 \mathrm{~s}\right.$ at $\left.72^{\circ}\right)$. After the end of cycling, the material was cooled down to $40^{\circ}$ for $60 \mathrm{~s}$. Fluorescence levels were read at $560-\mathrm{nm}$ wavelength, specific for JOE fluorophore dye [10]. Every tested sample was amplified along with an internal control (positive control of DNA amplification process). For the assessment of reaction specificity, DNA isolated from the following viruses was used: HHV-1, HHV-5 and HHV-6. Each amplification reaction included, except tested samples, also positive HHV-7 controls (RK strain) in a range of 100100,000 copies/ml and a negative control of DNA extraction and the amplification process [10].

HHV-5 DNA was detected using the commercially available quantitative CMV Quant Kit ${ }^{\circledR}$ (Roche Diagnostics) developed especially for monitoring cytomegalovirus disease with the LightCycler 2.0 instrument. The test uses SCORPIONSTM fluorescent probes. Analogically for HHV-7 detection, an internal control was added for every sample and amplification was performed in the presence of amplification-specific controls (positive, negative and extraction process control). 
Table 2. Characteristics and clinical status of patients positive for HHV-7 after HSCT

\begin{tabular}{|c|c|c|c|c|c|c|c|}
\hline $\begin{array}{l}\text { Patient } \\
\text { No. }\end{array}$ & Sex & $\begin{array}{l}\text { Age } \\
\text { years }\end{array}$ & Disease & SCT & $\begin{array}{l}\text { HHV-7 DNA in plasma } \\
\text { (days after SCT) }\end{array}$ & $\begin{array}{l}\text { HHV - } 5 \text { DNA in plasma } \\
\text { (days after SCT) }\end{array}$ & $\begin{array}{l}\text { Time and cause of death } \\
\text { (days after HSCT) }\end{array}$ \\
\hline 1 & male & 44 & AML & rPBSCT & $++(43-65)$ & - & $\begin{array}{l}\text { sepsis, multiorgan } \\
\text { failure (140) }\end{array}$ \\
\hline 2 & male & 43 & AML & rPBSCT & $+(30)$ & - & ARDS, shock (35) \\
\hline 3 & male & 56 & AML & rPBSCT & $++(48-56)$ & - & infection $(>500)$ \\
\hline 4 & male & 50 & $\mathrm{MM}$ & rPBSCT & $+(42)$ & - & infection $(>600)$ \\
\hline 5 & female & 22 & ALL & uPBSCT & $++(44-62)$ & - & $\mathrm{N} / \mathrm{A}$ \\
\hline 6 & female & 19 & ALL & rPBSCT & $+(48)$ & - & $\mathrm{N} / \mathrm{A}$ \\
\hline 7 & female & 26 & AML & rPBSCT & $+(40)$ & - & $\mathrm{N} / \mathrm{A}$ \\
\hline 8 & female & 39 & AML & rPBSCT & $+(52)$ & - & N/A \\
\hline 9 & female & 19 & ALL & uPBSCT & $+(22)$ & - & $\begin{array}{l}\text { infection, hemorrhage } \\
\text { within CNS (25) }\end{array}$ \\
\hline 10 & male & 49 & MM & rPBSCT & $+(20)$ & - & GvHD (25) \\
\hline 11 & female & 25 & AML & rPBSCT & $++(38-55)$ & $+(55)$ & N/A \\
\hline 12 & female & 31 & $\mathrm{HD}$ & rPBSCT & $++(42-58)$ & $++(55-68)$ & $\mathrm{N} / \mathrm{A}$ \\
\hline 13 & male & 45 & AML & uPBSCT & $++(32-50)$ & $++(58-74)$ & $\mathrm{N} / \mathrm{A}$ \\
\hline 14 & female & 19 & AML & uPBSCT & $++(42-60)$ & $++(56-70)$ & $\mathrm{N} / \mathrm{A}$ \\
\hline 15 & male & 56 & CLL & rPBSCT & $+(38)$ & $++(42-70)$ & $\mathrm{N} / \mathrm{A}$ \\
\hline 16 & male & 30 & AML & uBMT & $++(45-50)$ & $++(50-72)$ & sepsis (140) \\
\hline 17 & male & 48 & AML & rPBSCT & $+(33)$ & - & N/A \\
\hline 18 & female & 33 & AML & uPBSCT & $++(40-50)$ & $+(55)$ & $\mathrm{N} / \mathrm{A}$ \\
\hline 19 & female & 51 & $\mathrm{HD}$ & rPBSCT & $+(34)$ & - & $\mathrm{N} / \mathrm{A}$ \\
\hline 20 & male & 19 & AML & uPBSCT & $+(50)$ & $++(54-68)$ & pneumonia (220) \\
\hline 21 & female & 24 & SAA & uPBSCT & $++(44-56)$ & $++(60-80)$ & N/A \\
\hline 22 & male & 27 & CML & uPBSCT & $++(28-42)$ & - & $\mathrm{N} / \mathrm{A}$ \\
\hline 23 & female & 25 & $\mathrm{HD}$ & rPBSCT & $+(30)$ & - & $\mathrm{N} / \mathrm{A}$ \\
\hline 24 & female & 42 & AML & uPBSCT & $++(34-42)$ & $++(52-65)$ & $\mathrm{N} / \mathrm{A}$ \\
\hline 25 & female & 56 & AML & uPBSCT & $++(20-35)$ & - & $\mathrm{N} / \mathrm{A}$ \\
\hline 26 & male & 26 & AML & uPBSCT & $++(42-52)$ & $+(58)$ & pneumonia (200) \\
\hline
\end{tabular}

$\mathrm{ALL}=$ Acute lymphoblastic leukemia; $\mathrm{AML}=$ acute myeloid leukemia; CLL = chronic lymphoblastic leukemia; $\mathrm{CML}=$ chronic myeloid leukemia; HD = Hodgkin's disease; $\mathrm{MM}=$ multiple myeloma; SAA = severe aplastic anemia; SCT = stem cell transplantation; $r$ PBSCT $=$ related peripheral blood stem cell trans- plantation; $\mathrm{uPBSCT}=$ unrelated peripheral blood stem cell transplantation; $\mathrm{uBMT}=$ unrelated bone marrow transplantation; - = negative; $+=$ positive in one serum sample; $++=$ positive in two or more serum samples; ARDS = acute respiratory distress syndrome; CNS = central nervous system; N/A = not applicable.
Statistics was done with the Kruskal-Wallis rank test. We compared viral load in samples taken from patients with a single virus with that from patients who had $\beta$-herpesvirus coinfection.

\section{Results}

Positive results of $\mathrm{HHV}-7$-specific in-house real-time PCR, expressed as exponential gain of fluorescence at the desired wavelength, were detected in samples taken from 26 patients (45\%). Twelve of them (21\%) had determined HHV-7 DNA presence only in single positive samples; 14 (24\%) others had a positive result in two or more subsequent tests. Obtained quantitative results were usually at low to medium level, placed between 1,000-5,000 copies/ $\mathrm{ml}$, and viremia was observed between 20 and 65 days after transplantation (table 2). In control samples containing DNA from an uninfected Vero cell line, DNA isolated from HHV-1, HHV-5 and HHV-6, fluorescence was not observed, which speaks for high specificity of the method used.

As an amplification result of DNA isolated from plasma using the HHV-5-specific qPCR method, products were detected in samples taken from 16 individuals (28\%). HHV-5 DNA was also detected in the plasma samples collected from $11 \mathrm{HHV}-7$-positive patients. In all observed cases, HHV-5 DNAemia was found in the typical period of 40-80 days after transplantation, al- 
Table 3. Viral load in the different groups of patients for HHV-5 and HHV-7

\begin{tabular}{lllllllll}
\hline $\begin{array}{l}\text { Patient } \\
\text { group }\end{array}$ & Patients & $\begin{array}{l}\text { HHV-5 DNA } \\
\text { in plasma, days } \\
\text { after SCT }\end{array}$ & $\begin{array}{l}\text { Average } \\
\text { HHV-5 load } \\
\text { copies/ml }\end{array}$ & $\begin{array}{l}\text { Maximum } \\
\text { HHV-5 load } \\
\text { copies/ml }\end{array}$ & $\begin{array}{l}\text { HHV-7 DNA } \\
\text { in plasma, days } \\
\text { after SCT }\end{array}$ & $\begin{array}{l}\text { Average } \\
\text { HHV-7 load } \\
\text { copies/ml }\end{array}$ & $\begin{array}{l}\text { Maximum } \\
\text { HHV-7 load } \\
\text { copies/ml }\end{array}$ & $\begin{array}{l}\text { Mortality } \\
\text { \% } \\
\text { Average time } \\
\text { of death, days } \\
\text { after SCT }\end{array}$ \\
\hline $\begin{array}{l}\text { HHV-5+l } \\
\text { HHV-7+ }\end{array}$ & 11 & $34-80$ & 2,900 & 7,500 & $32-53$ & 2,200 & 5,000 & 18.2 \\
$\begin{array}{l}\text { HHV-5-l } \\
\text { HHV-7+ }\end{array}$ & 16 & N/A & N/A & N/A & $20-65$ & 1,400 & 3,500 & 37.5 \\
$\begin{array}{l}\text { HHV-5+l } \\
\text { HHV-7- }\end{array}$ & 5 & $43-71$ & 2,500 & 6,800 & N/A & N/A & N/A & 221 \\
$\begin{array}{l}\text { HHV-5-l } \\
\text { HHV-7- }\end{array}$ & 26 & N/A & N/A & N/A & N/A & N/A & N/A & 25.4 \\
\hline
\end{tabular}

ways placed in the range between $700-7,500$ copies $/ \mathrm{ml}$ (table 2).

Overall mortality in the entire group of HSCT recipients during the first 180 days after transplantation was $20.7 \%$ (12 patients from 58), and the most frequent direct death cause was: ARDS (4 patients), sepsis (4 patients) and pneumonia (2 patients). In the HHV-7-positive patients, mortality was $19.2 \%$ (5 patients from 26 ), but none of them died during detectable HHV-7 or HHV-5 viremia periods (table 2).

Results of statistical analysis of comparison of HHV-5 and HHV-7 load in sera samples revealed a statistically insignificant difference ( $p \geq 0.005$, Kruskal-Wallis rank test) between patients with a single $\beta$-herpesvirus detected and patients who had HHV-5 and HHV-7 coinfection.

\section{Discussion}

After primary infection, herpesviruses persist throughout life. Reactivation occurs usually under conditions of immunosuppression and can lead to illnesses that differ in clinical presentation from disease associated with primary infection. Reactivating HHV-7 has been associated with hepatitis in liver transplant patients [9], encephalitis in bone marrow transplantation [7] and sometimes with graft rejection $[7,11]$. Available data suggest that HHV-7 infections are common after transplantation and could implicate $\mathrm{HHV}-5$ reactivation and cy tomegalovirus disease $[7,12]$. The evidence between these two viruses is not consistent, because of absence of standardized diagnostic tests for HHV-7. Other authors have demonstrated that HHV-7 reactivation occurs earlier than $\mathrm{HHV}-5$, and HHV-7 has been implicated as a factor for subsequent HHV-5 reactivation and disease [7, 13]. Our observations show that HHV-7 viremia may also occur simultaneously at the time of active infection caused by HHV-5 (table 2, 3).

In our study, we found that $45 \%$ (26 individuals) of allogeneic graft recipients developed HHV-7 infection. Fourteen patients (24\%) had detectable viral DNA level in two or more samples in subsequent tests during the 10 weeks following allogeneic HSCT and other $12(21 \%)$ had a single positive sample in the same period (table 2). HHV-7 was probably reactivated from the recipient's own body by factors such as a profound immune dysfunction or an allogeneic reaction after transplantation. This is only our hypothesis, due to the lack of commercial serological methods for measuring presence of anti-HHV-7 antibodies.

We did not find any correlation between HHV-7 viremia and used conditioning regimen or anti-GvHD prophylaxis. Most of HHV-7-positive graft recipients during 10 weeks after SCT had fever of unknown etiology, and cytomegalovirus DNA was found in plasma samples taken from 11 individuals during or shortly after HHV-7 onset. No association between HHV-5 and/ or HHV-7 viremia and mortality was found in this study (table 2, 3).

HHV-7 could cause well-known clinical symptoms in allogeneic HSCT recipients, but has also indirect effects such as contributing to graft rejection and increasing the risk of additional cytomegalovirus infection [14, 15]. Nevertheless, the question of interactions between the $\beta$ herpesviruses is still pending. It seems likely that the impairment of the immune system by HHV-5 or other immunological events surrounding the transplantation might trigger an HHV-7 infection [15]. The availability of 
the qPCR technique means that diagnosis is available in a clinically helpful time frame, which should assist with implementing timely therapeutic intervention and assessing response to further treatment [16].

\section{Acknowledgements}

The authors are grateful to the Foundation for Patients with Haematological Diseases (Warsaw, Poland) for its kind support during the molecular studies on HHV-7. G.W. Basak is also recipient of the START Scholarship from the Foundation for Polish Science.

\section{References}

1 Davison A, Eberle R, Hayward GS, McGeoch DJ, Minson AC, Pellet PE: Herpesviruses; in Faquet CM, Mayo MA, Maniloff J, Desselberger U, Ball LA (eds): Virus Taxonomy Classification and Nomenclature of Viruses. Eighth report of ICTV. San Diego, Elsevier Academic Press, 2005, pp 193-212.

$\checkmark 2$ Kosuge H: HHV-6, 7 and their related diseases. J Dermatol Sci 2000;22:205-212.

3 Yamanishi K: Human herpesvirus 6 and human herpesvirus 7; in Richman DD, Whitley RJ, Hayden FG (eds): Clinical Virology. Washington, ASM Press, 2002, pp 463-478.

4 Tanaka K, Kondo T, Torigoe S, Okada S, Mukai T, Yamanishi K: Human herpesvirus 7: another causal agent for roseola (exanthema subitum). J Pediatr 1994;125:1-5.

5 Chuh AA: The association of pityriasis rosea with cytomegalovirus, Epstein-Barr virus and parvovirus B19 infections - a prospective case control study by polymerase chain reaction and serology. Eur J Dermatol 2003; 13:25-28.

6 Yoshikawa T, Black JB, Ihira M, Suzuki K, Suga S, Iida K, Saito Y, Asonuma K, Tanaka $\mathrm{K}$, Asano Y: Comparison of specific serological assays for diagnosing human herpesvirus 6 infection after liver transplantation. Clin Diagn Lab Immunol 2001;8:170-173.
7 Chan PKS, Peiris JSM, Yuen KY, Liang RHS Lau YL, Chen FE, Lo SK, Cheung CY, Chan TK, Ng MH: Human herpesvirus- 6 and human herpesvirus-7 infections in bone marrow transplant recipients. J Med Virol 1997; 53:295-305

-8 Osman HK, Peiris JS, Taylor CE, Warwicker P, Jarrett RF, Madeley CR: Cytomegalovirus disease in renal allograft recipients: is human herpesvirus 7 a cofactor for disease progression? J Med Virol 1996;48:295-301.

\$9 Griffiths PD, Ait-Khaled M, Bearcroft CP, Clark DA, Quaglia A, Davies SE, Burroughs AK, Rolles K, Kidd IM, Knight SN, Noibi SM, Cope AV, Phillips AN, Emery VC: Human herpesviruses 6 and 7 as potential pathogens after liver transplant: prospective comparison with the effect of cytomegalovirus. J Med Virol 1999;59:496-501.

10 Dzieciatkowski T, Przybylski M, Kawecki D, Midak-Siewirska A, Gierynska M, Luczak M, Mlynarczyk G: Application of real-time PCR and LightCycler ${ }^{\circledR}$ system for investigating the presence of human herpesvirus 7 DNA. Med Dosw Mikrobiol 2009;61:93-98.

11 Wang FZ, Dahl H, Linde A, Brytting M, Ehrnst A, Ljungman P: Lymphotropic herpesviruses in allogeneic bone marrow transplantation. Blood 1996;88:3615-3620.
12 Kidd IM, Clark DA, Sabin CA, Andrew D, Hassan-Walker AF, Sweny P, Griffiths PD, Emery VC: Prospective study of human betaherpesviruses after renal transplantation: association of human herpesvirus 7 and cytomegalovirus co-infection with cytomegalovirus disease and increased rejection. Transplantation 2000;69:2400-2404.

13 Mendez JC, Dockrell DH, Espy MJ, Smith TF, Wilson JA, Harmsen WS, Ilstrup D, Paya $\mathrm{CV}$ : Human beta-herpesvirus interactions in solid organ transplant recipients. J Infect Dis 2001;189:179-184.

14 Griffiths PD, Clark DA, Emery VC: Betaherpesviruses in transplant recipients. J Microb Chem 2000;45:29-34.

- 15 Humar A, Asberg A, Kumar D, Hartmann A, Moussa G, Jardine A, Rollag H, Mouas H, Gahlemann CG, Pescovitz MD: An assessment of herpesvirus co-infections in patients with CMV disease: correlation with clinical and virologic outcomes. Am J Transplant 2009;9:374-381.

16 Sassenscheidt J, Rohayem J, Illmer T, Bandt D: Detection of beta-herpesviruses in allogenic stem cell recipients by quantitative real-time PCR. J Virol Methods 2006;138:4048. 